\title{
Hypothyroidism Causing Precocious Puberty and Ovarian Torsion
}

\section{Sandesh Kini, Ramesh Bhat Y, Phalguna Kousika, Chennakeshava Thunga, Koushik Handattu and Lakshmikanth Halegubbi Karegowda}

Department of Paediatrics, Kasturba Medical College, Manipal Academy of Higher Education, Manipal, Karnataka, India.

\section{Correspondence: \\ Ramesh Bhat Y \\ Department of Paediatrics \\ Kasturba Medical College, Manipal, \\ Manipal Academy of Higher Education, \\ Manipal, Karnataka, India \\ E-mail: ramesh.bhaty@manipal.edu}

DOI: $10.3126 /$ jnps.v39i3.23815

Submitted on: 2019-04-24

Accepted on: 2020-05-06

Acknowledgements: None

Funding: Nil

Conflict of Interest: None declared

Permission from IRB: Yes
To cite this article: Kini $\mathrm{S}$, Bhat $\mathrm{R}$, Kousika P, Thunga C, Handattu K, Karegowda LH. Hypothyroidism causing precocious puberty and ovarian torsion. $\mathrm{J}$ Nepal Paediatr Soc. 2019;39(3):185-8.

\section{ABSTRACT}

Hypothyroidism in children causes delayed puberty. However longstanding untreated hypothyroidism can lead to precocious puberty which may be secondary to hyperprolactinemia or increased levels of thyroid stimulating hormone (TSH), enhancing the sensitivity of ovaries to circulating gonadotropins. Here we report a seven and half years old girl with hypothyroidism presenting with precocious puberty and multicystic ovaries which responded well to thyroid hormone supplementation but subsequently developed left ovarian torsion requiring surgical intervention.

Key words: hypothyroidism; precocious puberty; ovarian torsion

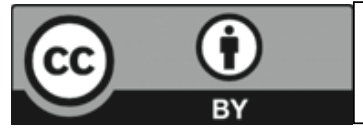

This work is licensed under creative common attribution 3.0 license 


\section{INTRODUCTION}

Long standing primary hypothyroidism associated with isosexual precocious puberty and multicystic enlarged ovaries constitute a clinical syndrome named as Van Wyk- Grumbach Syndrome (VWGS). ${ }^{1}$ Girls with VWGS have breast development with or without galactorrhea, follicular cysts of ovaries causing bilateral ovarian masses, and menstruation in absence of pubic or axillary hair whereas boys have macroorchidism with minimal penile enlargement but no significant signs of virilization. ${ }^{1}$ In this report, a seven and half years old girl presented with isosexual precocious puberty with multiple ovarian cysts and underlying hypothyroidism which subsequently resulted in ovarian torsion requiring surgical intervention.

\section{CASE REPORT}

A seven and half years old girl child presented with menstrual bleeding, four to five days in a month, since last two months. She also complained of abdominal pain during the episodes. Mother also gave history of recent weight gain which was not quantified. The child was developmentally normal with good scholastic performance and no significant past history except for poor height gain. She was a first born child of a third degree consanguineous marriage. At presentation her anthropometric measurements on WHO 2007 reference charts were as follows: height $97.5 \mathrm{~cm}$ $\left(<3^{\text {rd }}\right.$ centile), weight- $17.8 \mathrm{~kg}$ (between $3^{\text {rd }}$ to $15^{\text {th }}$ centile) and head circumference- $48.5 \mathrm{~cm}(<-2 \mathrm{SD})$. The mid parental height was $150.75 \mathrm{~cm}$. The upper segment to lower segment ratio was 1.05:1, suggestive of proportionate short stature. Her

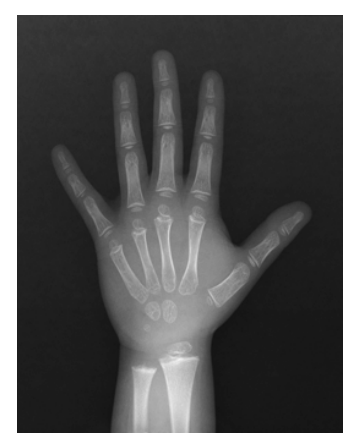

Figure 1. Frontal radiograph of wrist and hand showing visualisation of three carpal bones corresponding to bone age of around four years height age was three years and four months. Her arm span was $95 \mathrm{~cm}$. On examination she had tanner stage 3 breast enlargement without pubic hair and normal external genitalia. Systemic examination was normal. Her wrist X-ray showed a bone age corresponding to four years on GreulichPyle atlas as depicted in figure 1 .

Ultrasound abdomen showed bulky uterus with enlarged ovaries with cystic areas (right ovary measuring $7.0 \times 4.2 \times 3.8 \mathrm{~cm}$ with multiple cysts largest measuring $2.4 \times 2.0 \times 2.1 \mathrm{~cm}$ and left ovary measuring $10.0 \times 7.0 \times 8.0 \mathrm{~cm}$ with few large cysts, largest measuring $5.4 \times 4.5 \times 5.0 \mathrm{~cm}$ with septations) as depicted in figure 2 .

MRI brain showed homogenously enhancing bulky anterior pituitary gland bulging upwards with convex superior margin measuring $15.0 \mathrm{~mm}$ in height suggestive of pituitary hyperplasia as depicted in figure 3. Thyroid scan with Tc-99m pertechnetate showed eutopic thyroid gland with both lobes of thyroid being mildly enlarged in size and showing uniformly increased radiotracer concentration.

Child was started on thyroxine 100 mcg once daily and monthly dose of injection progesterone depot $100 \mathrm{mcg}$ intra muscularly. She also received oral iron supplementation for three months. Child was followed up every month and during subsequent follow up child gradually gained height but continued to have spotting during periods. At six months follow up her height was $105.5 \mathrm{~cm}$ and weight was $15.8 \mathrm{~kg}$. Thyroid function tests at 6 months follow up showed T3-1.42 ng/ml, T4- 10.58 $\mu \mathrm{g} / \mathrm{dl}$, TSH- $3.57 \mu \mathrm{IU} / \mathrm{ml}$ and thyroxine was gradually tapered to $50 \mu \mathrm{g} /$ day. Her haemoglobin improved to $11.3 \mathrm{~g} / \mathrm{dl}$. A routine ultrasound scan at six months follow up showed torsion of the left
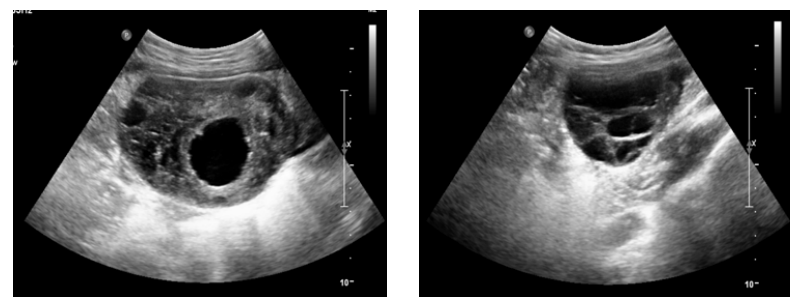

Figure 2. Ultrasound image of left and right ovaries showing multiple follicles with cysts 


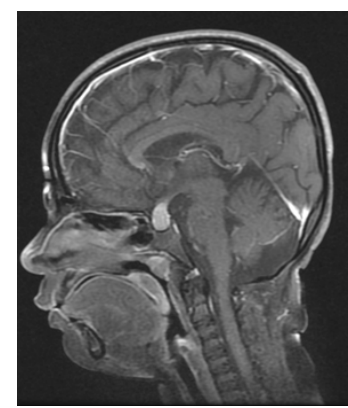

Figure 3. Sagittal post contrast T1 weighted image showing enlarged pituitary gland with convex upper margin showing suprasellar extension with no sellar widening suggestive of pituitary hyperplasia.

ovary. MRI scan of the pelvis showed a heterogenous lesion in the right adnexa which was heterogeneously hyperintense on $\mathrm{T} 2$, hyperintense on $\mathrm{T} 1$ and $\mathrm{T} 1$ fat suppressed sequences with no significant post contrast enhancement suggestive of left ovarian torsion. However, child had no symptoms of pain abdomen or vomiting. Paediatric surgery consultation was sought and she underwent left ovarian detorsion with right oopheropexy. She is on regular follow up and doing well.

\section{DISCUSSION}

Hypothyroidism associated with precocious puberty was first described by Van Wyk and Grumbach in $1960 .{ }^{1}$ Several theories have been put forward regarding hypothyroidism causing precocious puberty. High levels of TSH in untreated hypothyroidism stimulates FSH receptors and produces FSH like effects causing multicystic ovaries and menstrual bleeding. ${ }^{2}$ In long standing untreated hypothyroidism prolactin levels are high. This is due to the fact that prolactin and TSH share the same thyroid regulating hormone (TRH). As a result of chronic stimulation of TRH there is increased sensitivity of the ovaries to circulating gonadotropins. ${ }^{3}$ Generally precocious puberty due to other etiologies causes tall stature with increased pubertal growth spurt and advanced bone age whereas in hypothyroidism there is short stature with delayed bone age. The cause of hypothyroidism in these cases is often due to lymphocytic thyroiditis ${ }^{4}$ and our findings were similar with elevated thyroid antibody levels. Supplementation of thyroid hormones results in regression of ovarian cysts and cessation of vaginal
Table 1. Blood investigation reports

\begin{tabular}{|c|c|c|}
\hline $\begin{array}{l}\text { Laboratory } \\
\text { parameters }\end{array}$ & $\begin{array}{l}\text { Patient's } \\
\text { value }\end{array}$ & $\begin{array}{r}\text { Normal Values } \\
\text { for age }\end{array}$ \\
\hline Haemoglobin & $7.5 \mathrm{~g} / \mathrm{dl}$ & $11.5-15.5 \mathrm{~g} / \mathrm{dl}$ \\
\hline $\mathrm{MCV}$ & $83.7 \mathrm{fl}$ & 73.9-87.4 fl \\
\hline $\mathrm{MCH}$ & $27.9 \mathrm{pg}$ & $23.6-31.0 \mathrm{pg}$ \\
\hline $\mathrm{MCHC}$ & $33.3 \mathrm{~g} / \mathrm{dl}$ & $31.9-36.9 \mathrm{~g} / \mathrm{dl}$ \\
\hline RDW & $12.5 \%$ & $11.5-14.5$ \\
\hline Reticulocyte count & $1.96 \%$ & $0.5-2.5$ \\
\hline Platelet count & $\begin{array}{l}286.0 \times 103 / \\
\mu \mathrm{L}\end{array}$ & $\begin{array}{r}150.0-450.0 \mathrm{x} \\
103 / \mu \mathrm{L}\end{array}$ \\
\hline Total WBC count & $9.4 \times 103 / \mu \mathrm{L}$ & $\begin{array}{r}4.5-14.5 \times 103 / \\
\mu \mathrm{L}\end{array}$ \\
\hline $\begin{array}{l}\text { Differential count-N/ } \\
\mathrm{L} / \mathrm{M} / \mathrm{E}(\%)\end{array}$ & $\begin{array}{l}60.5 / 29.9 / 7.6 \\
/ 1.5\end{array}$ & \\
\hline $\mathrm{T} 3$ & $0.3 \mathrm{ng} / \mathrm{ml}$ & $0.94-2.41 \mathrm{ng} / \mathrm{ml}$ \\
\hline $\mathrm{T} 4$ & $0.8 \mathrm{mcg} / \mathrm{dl}$ & $6.4-13.3 \mathrm{mcg} / \mathrm{dl}$ \\
\hline TSH & $\begin{array}{l}>100 \mu \mathrm{IU} / \\
\mathrm{ml}\end{array}$ & $0.6-6.3 \mu \mathrm{IU} / \mathrm{ml}$ \\
\hline $\begin{array}{l}\text { Anti-TPO antibody } \\
\text { levels }\end{array}$ & $205.1 \mathrm{IU} / \mathrm{ml}$ & upto $34 \mathrm{IU} / \mathrm{ml}$ \\
\hline $\begin{array}{l}\text { Anti-Tg antibody } \\
\text { levels }\end{array}$ & $123.8 \mathrm{IU} / \mathrm{ml}$ & $1-115 \mathrm{IU} / \mathrm{ml}$ \\
\hline FSH (baseline) & $10.5 \mathrm{mIU} / \mathrm{ml}$ & $0.0-2.8 \mathrm{mIU} / \mathrm{ml}$ \\
\hline LH (baseline) & $\begin{array}{l}<0.1 \mathrm{mIU} / \\
\mathrm{ml}\end{array}$ & $0.0-1.6 \mathrm{mIU} / \mathrm{ml}$ \\
\hline Estradiol (baseline) & $47.4 \mathrm{pg} / \mathrm{ml}$ & $<25 \mathrm{pg} / \mathrm{ml}$ \\
\hline Prolactin & $86.1 \mathrm{ng} / \mathrm{ml}$ & $4.77-23.21 \mathrm{ng} /$ \\
\hline Cortisol & $14.8 \mathrm{mcg} / \mathrm{dl}$ & $5.7-16.6 \mathrm{mcg} / \mathrm{dl}$ \\
\hline $\begin{array}{l}\text { FSH } \\
(\text { post challenge })^{\Omega}\end{array}$ & $11 \mathrm{mIU} / \mathrm{ml}$ & \\
\hline $\begin{array}{l}\mathrm{LH} \\
(\text { post challenge })^{\Omega}\end{array}$ & $<0.1 \mathrm{mIU} / \mathrm{ml}$ & \\
\hline 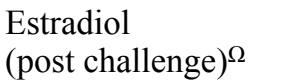 & $57.9 \mathrm{pg} / \mathrm{ml}$ & \\
\hline
\end{tabular}

MCV-mean corpuscular volume, MCH- mean corpuscular haemoglobin, MCHC- mean corpuscular haemoglobin concentration, $R D W$ - red cell distribution width, $N$ neutrophils, L- lymphocyte, M- monocyte, E- eosinophil, TSH-thyroid stimulating hormone, TPO-thyroid peroxidase, Tg- thyroglobulin, FSH-follicle stimulating hormone, LHluteinizing hormone. $\Omega$-following injection leuprolide 400 mcg intramuscular administration. 
bleeding with good height gain ${ }^{5}$ as evident in the present case. Thyroid functions should be tested in a child with precocious puberty and ovarian mass to look for hypothyroidism so as to avoid unnecessary surgeries. However, in the present case the child had ovarian torsion which required surgery. Acute ovarian torsion has been reported as a complication of untreated profound hypothyroidism. ${ }^{6}$ A similar case has been reported from Delhi where hypothyroidism was detected after the child underwent bilateral salpingooophorectomy for bilateral ovarian torsion. ${ }^{7}$ Ovarian torsion has also been reported following gonadotropin releasing hormone analogue therapy with leuprolide acetate ${ }^{8}$ whereas in the present case child was receiving monthly progesterone acetate.

\section{CONCLUSIONS}

Hypothyroidism should be considered in girls presenting with precocious puberty with short stature and multicystic ovaries which can be successfully treated with thyroid hormone supplementation. Untreated hypothyroidism can lead to acute ovarian torsion which can be easily avoided if intervened early.

\section{REFERENCES}

1. Naznin L, Saha S, Saha D, Sultana S, Mj C. Van Wyk- Grumbach Syndrome - An Unusual Presentation of Severe Hypothyroidism. JAFMC Bangladesh. 2015;11(1):2-5. DOI: https://doi.org/10.3329/jafmc.v11i1.30684.

2. Indumathi CK, Bantwal G, Patil M. Primary Hypothyroidism with Precocious Puberty and Bilateral Cystic Ovaries. Indian J Pediatr. 2007;74(8):781-3. DOI: https://doi.org/10.1007/s12098-007-0140-9.

3. Radaideh M, Nusier M, El-akawi Z, Jaradat D. Precocious puberty with congenital hypothyroidism. Neuroendocrinol Lett. 2005;26(3):3-6. PMID: 15990731.

4. Sharma D, Dayal D, Gupta A, Saxena A. Case Report Premature Menarche Associated with Primary Hypothyroidism in a 5.5-Year-Old Girl. Case Rep Endocrinol. 2011:6-9. DOI:10.1155/2011/678305.

5. Ghaemi N, Vakili R, Bagheri S. Precocious Puberty: An Unusual Presentation of Hypothyroidism. Int J Paediatr. 2013;1(2):51-4. DOI: 10.22038/IJP.2013.2165.

6. Nandi-munshi AD, Tridgell A. Acute Ovarian Torsion and Primary Hypothyroidism. Paediatrics. 2013;132(1). doi: 10.1542/peds.2012-3574.

7. Agarwala S, Gupta A. Primary Hypothyroidism Presenting as Bilateral Ovarian Torsion. Indian Paediatr. 2018;55 (77). PMID: 29396948.

8. Carvalho JP, Diegoli MS, Carvalho FM, Diegoli CA. Adnexal torsion following gonadotropin-releasing hormone analog therapy : A case report. Rev. Hosp. Clin. Fac. Med. S. Paulo. 2004;59(3):128-30. DOI:10.1590/ s0041-87812004000300006. 